\title{
COMPARATIVE STUDY OF DEVELOPMENT PATTERNS OF HIGHER EDUCATION IN IRAN AND NORWAY
}

\author{
Ali Ashrafi \\ Lecturer at English Department, \\ University of Applied Science and Technology, Tehran, Iran \\ ORCID: 0000-0002-2427-6509, e-mail: Ali.Ashrafi.Sarvak11@gmail.com
}

Education is one of the most important factors of every social system. According to the development of working and living skills in the current situation, the educational system of any society needs to be enhanced qualitatively and quantitatively. Then, taking advantages of policies and experiences of other countries in designing the educational system is very useful. Given that the purpose of the higher education system is to research and train the specialist community needed and plays an important role in the development of society. The research methodology is based on the collection of information from the Internet and library resources, referring to institutions related to the higher education system, as well as the Norwegian Embassy. The research method is based on Isak Kandal's historical method, which consists of three stages including a list of materials based on descriptions and historical application and Melioristic.

Key words: Comparative Education, Iran, Norway, Higher Education

Освіта є одним з найважливіших факторіВ розвитку кожної соціальной системи. На съогодні відбувається розвиток життевих навичок, тому й система осВіти будь-якого суспільства потребує якісного та кількісного покращення. Тому передовии досвід та політика іниих крайн у розбудові сис-теми осВіти є дуже корисним. Враховуючи ие, мета системи вищої освіти полягає у дослідженні потреб суспільства та підготовиі фохівиів, необхідних спільноті. Методологія дослідження грунтується на зборі інформачії з Інтер-нету та бібліотечних ресурсів, що стосується установ, пов'язаних з систе-мою вищої освіти, а також посольства Норвегіï. Метод дослідження базує-ться на історичному методі Ісака Кандала, який складається з трьох етапів, бключаючи перелік матеріалів на основі описів та історичного застосування, а також меліористичний етап.

Ключові слова: порівняльна педагогіка, Іран, Норвегія, вища осъіта.

Introduction. Nowadays, all nations with any advanced political and social systems are particularly interested in the issue of planning and educational reform. Investigation of the history of the evolution of the world successful educational systems shows that in order to achieve this, most of the leading countries have used comparative studies and research in the field of education and it is used as the condition for designing their new educational systems and emphasize the necessity of such studies before undertaking any comprehensive educational reformation to meet their growing economic, cultural and technical requirements. Rapid growing in science and technology have naturally led to a change in 
the socio-economic and cultural requirements and expectations of centres and institutions of higher edu-cation. The quantitative and qualitative analysis of the higher education system and the strategies used in various educational, research, administrative, and support departments of the system showing several failures (Jarsgatan, 2007).

On the other hand, the higher education system is part of the educational system of different countries of the world and as part of development indicators for countries. Comparative studies of education provide increased insight and vision for educational planners and help the administrators to discover educational truths, to analyse educational mistakes and to take treatment (Mohammadi et al 2008). In according to the abovementioned issues, most countries of the world use compa-rative studies and the necessity of reforms in the higher education system to adapt the needs of society and global issues, to carry out educational reforms. Therefore, studying the process of developing and recognizing the characteristics of higher education in successful countries of the world and using their experiences in dealing with challenges, frustrations and innovative programs can contribute to our consi-dering social, economic, political and historical conditions. Therefore, the aim of this study is to identify the process of quantitative and qualitative development and characteristics of the higher education system in Norway and compare it with the evolution of the higher education system of Iran. It will be possible to find out the strengths and weaknesses of the quantitative and qualitative growth of the higher education system in Iran based on this comparison. In this study three questions including 1) the evolution of the high education system and educational innovations in the countries of Iran and Norway 2) goals and missions of the higher education system in the countries of Iran and Norway and 3) relations between universities and industries and economics were answered.

Literature Review. Karimizadeh (2007) in a research paper entitled Analytical and Comparative Study of Student Selection Methods for Entry to Universities and Higher Education Institutions in Japan, Turkey, and Iran. In all three countries, Iran, Turkey, and Japan, the success of the university entrance examination depends on the student's academic record, the overall grade and the entrance examination and the type of field of study, and the competition for admission to state universities is more severe than to nongovernmental universities. Student enrolment in Iran is centrally-based and through national enrolment for the entire country, regardless of the characteristics of areas and educational facilities in each region, while in Japan, a decentralized approach is used to select students. The International Institute for Educational Design in 2004 reviewed educational reforms in Nordic countries (Sweden, Denmark, Finland, and Norway) (Kyvik, 1998). The higher education systems of these countries have been affected by technological change, globalization, and competition in recent years. Jakob et al. have studied the status of higher edu-cation in Norway since 1980 in the study conducted at the University of London concerning the assessment of the effectiveness of the higher education system in Norway (2010). Also, the higher education system in Norway has been influenced by the German higher education system, and in particular the view of the Hemisphere. The result of educational reforms in Norway from 2002 to 2006 was the greater independence of most institutions in managing and organizing its activities, increasing the independence and accountability of higher education institutions made fundamental changes both in methods and tools for higher education and in policymakers and statesmen (2008).

Higher education as a system consists of several components that are mutually interdependent and interact with each other. Therefore, the reinforcement of each aspect of higher education results in better performance of its components, and deficiency in each of them will reduce the efficiency in other sectors.

Higher education in Iran is divided into two parts: governmental and 
nongovernmental. Government Higher Education is part of higher education, which is financed by public funds. Governmental education is divided into two parts: medical and non-medical. Non-medical higher education forms the main part of higher education. Nongovernmental higher education funding is provided by the sources other than the state budget, including Islamic Azad University, non-govern-mental higher education institutions.

On the other hand, Norway is one of the richest member countries, due to its rich oil and gas resources in the cooperation of the Organization for Economic Cooperation and Development (OECD). But the more obvious reason for this is the management of these resources. In addition, the country's unemployment rate is low and the country's population is 5.258 million, which is relatively small in comparison size. The Norwegian higher education system is divided into two major parts (the academic and college sectors). There are four universities and six colleges in Norway. The college consists of 26 institutes, focusing on technical training and short courses such as undergraduate and in-service programs.

Methodology. The method of studying and analyzing information in this research is based on Kundel's method. Kundel's method contains three steps: first, the list of contents based on the description. At the first stage, the facts about the educational system of the studied countries are briefly outlined. The second stage is a cultural application. In the second stage, the researcher must consider the differences and factors that produce education problems that are the result of the factors governing the community. In the final stage, the researcher, based on the philosophic vision, compares his education system better with the comparison scale and names as Melioristic.

Results and Discussion. The first Norwegian higher education institute was founded in 1811 (Oslo University). In 1905, Norway became independent of the Kingdom of Sweden. With the rapid growth of Norwegian doctors in the early 1960s, which generally took place in all parts of the world, the debate about the growth of students and employers, and the developments in curricula and quality of education by the Norwegian government and parliament was considered by the commissions of higher education. In the 1970s, the Norwegian educational system was adapted from the American educational system, especially in higher education, and so autonomy of universities, educational decentralization, and quality assess-ment were considered. The Norwegian network had been discussed since the 1980s, and all Norwegian institutions were required to work together within the framework of the Norwegian Network. In the 1990s, the policy of aligning institutions in terms of quality, internationalization was prioritized, and in the next decade (from 2000 onwards), the policy of further independence of the institutions was considered by the accreditation institutions, cooperation under the Bologna program and coordination with market demand.

The evolution of higher education in the studied countries

\begin{tabular}{|c|c|c|}
\hline Country & Iran & Norway \\
\hline $\begin{array}{c}\text { The basic of } \\
\text { excellent } \\
\text { education }\end{array}$ & $\begin{array}{l}\text { Population growth, } \\
\text { rising demand for } \\
\text { higher education, } \\
\text { not considering } \\
\text { cultural and social } \\
\text { conditions }\end{array}$ & $\begin{array}{l}\text { Population growth, rising demand for } \\
\text { higher education, labour market need, } \\
\text { attention to regional, national and } \\
\text { transnational needs and global } \\
\text { developments, attention to cultural and } \\
\text { social conditions }\end{array}$ \\
\hline
\end{tabular}




\begin{tabular}{|c|c|c|}
\hline $\begin{array}{c}\text { The amount of } \\
\text { coordinated } \\
\text { quantitative } \\
\text { development } \\
\text { with qualitative } \\
\text { development }\end{array}$ & $\begin{array}{c}\text { There has been less } \\
\text { attention to quality } \\
\text { development }\end{array}$ & Parallel move together \\
\hline $\begin{array}{c}\text { Educational } \\
\text { innovation }\end{array}$ & $\begin{array}{c}\text { Creating science } \\
\text { and technology } \\
\text { park, internet access } \\
\text { to universities for } \\
\text { users }\end{array}$ & $\begin{array}{c}\text { Create a Norwegian network, establishing } \\
\text { a scientific collaboration network between } \\
\text { universities in Nordic countries, } \\
\text { internationalization of higher education }\end{array}$ \\
\hline
\end{tabular}

Then, in the next step, the relationship between universities and the industry and economy in terms of educational cooperation has been investigated. In Iran, the design of higher education is not based on the need for industrial and economic development. The higher education does not have any outcomes for the university, and the graduates' employment responsibilities do not have higher education.

The records of university curriculum planning and higher education institutions in Iran show that academic programs have not been coordinated not only with economic, social and cultural programs for the past years, but also regardless of regional needs, interests of students are designed and the needs of the labour market are not there, and even there is no responsible organization for this issue in Iran.

But in Norway, due to the developments of the 1960s and the rapid growth of students, the Norway government formed commissions for coordination in employ-ment and development programs and the need for the labour market has always been taken into account in the curriculum reform program.

Table 2

\section{Relationship of a higher education system with the labour market and employment in studied countries}

\begin{tabular}{|c|c|c|}
\hline $\begin{array}{c}\text { Country } \\
\text { The relationship } \\
\text { between the } \\
\text { industrial sectors. }\end{array}$ & $\begin{array}{c}\text { Iran } \\
\text { The need for the } \\
\text { labour market and } \\
\text { the industrial sector } \\
\text { in the design of } \\
\text { higher education is } \\
\text { weak }\end{array}$ & $\begin{array}{c}\text { Norway } \\
\text { between apprenticeship and } \\
\text { research, attention is paid to } \\
\text { the needs of the labour } \\
\text { market and to the status of } \\
\text { graduates of universities } \\
\text { every year }\end{array}$ \\
\hline Criticisms & $\begin{array}{c}\text { Targeting and policy- } \\
\text { making in relation to } \\
\text { the interaction of } \\
\text { universities and the } \\
\text { industrial sector are } \\
\text { weak. }\end{array}$ & $\begin{array}{c}\text { The functioning of the higher } \\
\text { education system depends on } \\
\text { the market need and the } \\
\text { social goals of higher } \\
\text { education are }\end{array}$ \\
\hline
\end{tabular}

And finally, researchers have shown that the purposes of the higher education 
system in Iran and Norway. In Norway, higher education objectives including: Give people the opportunity to grow their own, caring for common culture and growing competition among people, the growth of social democracy and the strengthening of critical debate, contribute to create social and military structures, Strengthening cooperation with international institutions, Development of equality between men and women, Development of new knowledge and new findings in different sectors of society and the study of the features of higher education in the studied countries show that their success in achieving goals is different. Iran encounters a huge gap and a great lack of coordination between social demand for higher education and student admissions. In Norway, it was observed that continuous educational reform, validation and quality assessment as a cultural infiltration in universities

Table 3

Higher education goals in studied countries

\begin{tabular}{|c|c|c|}
\hline Country & Iran & Norway \\
\hline Similar goals & $\begin{array}{c}\text { The production of science- } \\
\text { training the required specialist } \\
\text { force-the dissemination of } \\
\text { culture and knowledge in } \\
\text { society-the growth of social } \\
\text { democracy }\end{array}$ & $\begin{array}{c}\text { The production of science- } \\
\text { training the required specialist } \\
\text { force-the dissemination of culture } \\
\text { and knowledge in society-the } \\
\text { growth of social democracy }\end{array}$ \\
\hline Different goals & $\begin{array}{c}\text { Promotion of Islamic values } \\
\text { and its dissemination in the } \\
\text { national and international } \\
\text { dimension }\end{array}$ & $\begin{array}{c}\text { Training the critical thinking of } \\
\text { developing international } \\
\text { cooperation }\end{array}$ \\
$\begin{array}{c}\text { The method to } \\
\text { ameasure the }\end{array}$ & $\begin{array}{c}\text { Vice President of Strategic } \\
\text { Planning and Control }\end{array}$ & $\begin{array}{c}\text { A government-independent } \\
\text { organization called NUKUT } \\
\text { funded by the government, each } \\
\text { year, through the validation of } \\
\text { programs, determines the }\end{array}$ \\
actount of access to the goals. \\
\hline
\end{tabular}

Conclusion. As stated in the article, higher education as a specialist human resource educator has a special place in society. The development of higher education due to its missions is one of the main policies of the countries of the world. But, if there is a moderate relationship between the student population and the needs of the labour market and social, cultural, political needs of the country, the higher education will achieve its goals. The results showed that in Norway admission of students according to the labour market needs has taken place. These cases showed that the quantitative and qualitative expansion of the higher education system of Norway was not considered without regard to domestic and international needs, and when the needs for a reformation of goals and plans, the internal and international conditions are thoroughly investigated. But the study of the type and function of goals in Iran shows that the higher education system is an imported commodity and there is no connection between the goals of higher education and the cultural, economic, ethnic and labour market needs. In according to the studies of higher education characteristics of Iran and Norway, the following suggestions for developing higher 
education in Iran, are suggested:

Development of international educational cooperation.

Creating a network for scientific collaboration among higher education institutions to promote programs and activities.

Establishment of expert commissions to identify the barriers of communi-cation between the university and industry and the needs of the labour market.

Defining and targeting the higher education system as a factor in developing and solving socio-economic problems of the country.

\section{References:}

1. Jarsgatan, B. (2007). National policy for international higher education. National agency for higher education.

2. Mohammadi, D. H. Mirhosseini, S. (2008). A comparative investigation of academic promotion criteria in higher education. Journal of science and technology policy, vol. 1, no. 3.

3. Karimizadeh, N, (2008) Analytical review of student selection methods in Iran and Turkey. Ms. C Thesis, Tehran University.

4. Ministry of Education and Research, Norway (2008). Degree structure and grading system. Retrieved May 27, 2008. Available at: http://www.regjeringen.no/en/dep/kd/Selected-topics/Higher- Education/ Degree-structureand-grading-system.html?id $=491287$.

5. $\quad K y v i k . S$, Tevede, O. (1998). The doctorate in the Nordic countries.Comparative EducationVol. 34, No. 1 pp. 9 25

6. Nicoline. F. (2005). Fanding systems and their effects on the high education systems. Norwegian ministry of education \& research: 2005.

7. International Institute for educational planning (2004).Reforming higher education in the Nordic countries. Available at: https://rafhladan.is/bitstream/handle/10802/9520/139015e.pdf? sequence=1.

8. Ministry of Education and Research, Norway (2008). Higher education. Retrieved May 27, 2008. Available at: acwww.regjeringen.no/en/dep/kd/Selected-topics/Higher-Education.html?id.

9. Scott, G. (2010). Delivering higher education within further education in England: issues, tensions, and opportunities. Management in Education, vol. 24, no. 3, pp. 98-101.

Received: May, 16 Accepted: June, 10 